\section{İzmir İktisat Dergisi İzmir Journal of Economics}

ISSN:1308-8173

$\begin{array}{ll}\text { E-ISSN: } 1308-8505 & \text { YIL: } 2021 \\ \text { Kabul Tarihi: } 12.07 .2021 & \text { Online Yayın: 05.08.2021 }\end{array}$

Geliş Tarihi: 11.06 .2020
ÖZGÜN ARAŞTIRMA
Cilt: 36 Sayı: 2 Sayfa: $315-327$

Doi: 10.24988 /ije.202136205

\title{
Asymmetric and time-varying causality between the public and private sector investment: evidence from Turkey
}

\section{H. Hilal BAĞLITAŞ 1 , Pelin GENÇOĞLU ${ }^{2}$}

\begin{abstract}
The interaction between the private and public sectors is one of the main focuses of economics. They affect each other positively or negatively. This paper aims to determine the potential dynamic impacts of the public investments on the private investments in Turkey by running asymmetric causality and to detect a structural relationship of two sectors by using nonlinear and time-varying causality. The result illustrates that there is a crowding-out effect from the public to private investment. On the other side, time-varying and nonlinear causality reach an inverse direction for the causal effects stemming from the private to the public.
\end{abstract}

Keywords: : Causality, asymmetric causality, time-varying causality, crowding-out, crowding-in Jel Codes: E20, E62, H32, C33

\section{Kamu ve özel sektör yatırımı arasında asimetrik ve zamanla değişen nedensellik: Türkiye'den kanıtlar}

\section{Özet}

Ekonominin ana odak noktalarından biri, özel sektör ile kamu sektörü arasındaki etkileşimdir. Her iki kesim de birbirlerini olumlu veya olumsuz etkileyebilmektedir. Bu makalede, ilk olarak asimetrik nedensellik testi yapılarak, kamu kesimi yatırımlarının özel kesim yatırımları üzerindeki potansiyel dinamik etkilerinin tespit edilmesi amaçlanmaktadır. Ayrıca, Türkiye'de iki sektör arasındaki yapısal ilişsiyi tespit etmek için doğrusal olmayan ve zamanla değişen nedensellik analizleri kullanılmaktadır. Sonuçlar, kamudan özel sektöre doğru dışlama etkisi olduğunu göstermektedir. Bu sonucun yanında, doğrusal olmayan nedensellik ve zamanla değişen nedensellik testinde nedensel etkiler özel kesim yatırımlarından kamu kesimi yatırımlarına doğru gerçekleșmektedir.

Anahtar kelimeler: Nedensellik, asimetrik nedensellik, zamanla değişen nedensellik, dışlama, içselleme Jel Kodu: E20, E62, H32, C33

\section{INTRODUCTION}

In economics, one of the most studied topics is the role of government in macroeconomics. The reason is related to encouraging or deteriorating effects of government spending (consumption and investment) on the activities of private sector. These two situations are defined as crowding-in and crowding-out effect respectively. According to Purvis (1980), there are three kinds of crowding-out effects:
- The first kind occurs when the sensitivity of money demand to the interest rate is equal to zero (LM curve is vertical). Applying expansionary fiscal policy (IS curve shifts to the right) does not change income level with the fact that the fixed money supply causes interest rates to rise. Then, withdrawal in the private investment is the same amount as an increase in the fiscal policy. This effect is the original 'crowding-out effect'.

ATIF ÖNERÍsí (APA): Bağlıtaş, H. H., Gençoğlu, P. (2021). Asymmetric and time-varying causality between the public and private sector investment: evidence from Turkey. İzmir İktisat Dergisi. 36(2). 315-327 Doi: 10.24988/ije.202136205

${ }^{1}$ Res. Asst. Dr., Erciyes Üniversitesi, İktisadi ve İdari Bilimler Fakültesi, KAYSERİ,

EMAIL: hhilalbaglitas@gmail.com ORCID: 0000-0002-3031-6271

2 Dr., Erciyes Üniversitesi Kayseri Uygulama ve Araştırma Merkezi, KAYSERİ,

EMAIL: pgencoglu@erciyes.edu.tr ORCID: 0000-0003-2985-2875 
- $\quad$ The second kind is related to nominal changes in policies. For this step, the fullemployment level is a pre-assumption for the equilibrium. At this level, an expansionary fiscal policy leads to an increase in price level only. Thus, the quantity of real money decreases, and the real output level stays fixed at fullemployment. This kind shows no money illusion criteria.

- $\quad$ The third one is caused by funding type of government expenditures. If they are financed by bonds, interest rates rise inevitably. The right-shifted IS curve is eliminated by the left-shifted LM curve. Changes in private investment are equal changes in policy.

In addition to the classification described above, the crowding-out effect can occur through direct and indirect ways. When private sector investments are substituted by the public, this is a direct way for the crowding-out effect. The indirect way is more sophisticated, and the interest rate channel plays an important role as in the first and the third kind of crowding-out effect. When a fiscal stimulus (as a policy tool) causes transactions to rise, both the volume of consumption and investment would increase. At the same time, money demand based on these transactions also goes up and interest rates inevitably increase. At the end of the process, consumption and investment expenditures go down because of higher interest rates. This effect is termed the "transactional crowdingout effect" (Balcerzak and Rogalska, 2014: 8182).

Although the crowding-out effects of public investment are common, crowding-in effects also might exist. However, two effects most probably occur one after another if government purchases are financed by treasury bonds. Private agents (households and companies) buy these bonds to invest and at the time of sale, they want to sell these bonds. The price of bonds diminishes, and interest rates rise because of the increasing demand for money. At the end of the selling process, their wealth level rises until interest rate channel crowds-out them. In this way, firstly crowding-in takes place with the wealth-creating process and then crowding-out occurs. This crowdingin/out effect is called the "portfolio or wealth effect." It implies an increase or decrease in the wealth of economic agents (Balcerzak and Rogalska, 2014: 86)

To summarize, the shape of the relationship between the government and private sector is a dynamic pattern and this is especially prominent for developing countries (DEC). Their financial and fiscal structure is not strong enough to overcome the crisis and they might have weak institutional regulation and technological background. Thus, the private sectors of DEC are more sensitive to policy implementations than the private sector in developed countries. Furthermore, interactions between the public and private sectors might be unidirectional or bi-directional. Unidirectionality means a one-way direction relationship from the government sector to the private sector or vice versa. Bidirectionality means that feedback effects exist between them. In this context, causality analysis is an important technique to search the direction and types of causal effects.

Granger (1969) developed a linear causality, and this causality became one of the most important concepts for the econometric methodology. In a linear causality, there is consecutive order of cause and effect. Also, the relationship between them is direct, clear, and one-to-one (Six Causal Patterns, 2017). If the causality concept needs forward timestreaming, it means that there is a casual relationship between preceding event $X$ and subsequent event $Y$. If $X$ can forecast $Y$, there is Granger causality from $\mathrm{X}$ to $\mathrm{Y}$.

Hatemi-J (2011) argues that Granger implicitly evaluates causality on a symmetrical basis. Granger (1969) claims that linear parameters are easily interpreted and found out. With this logic, his approach to causal relationships is linear and symmetric. It means that absolute values of reactions for the positive and negative 
shocks are equal. Although symmetrical behaviors are correlated to the assumption of rationality, agents are closer to irrationality rather than rationality in the real world. Furthermore, their reactions to positive/negative policy shocks or up/downward movements in economic fluctuations might be highly different. The differences of reactions are 'asymmetry' and 'asymmetric in causality' for econometric analysis. Augmented Granger causality testing reflects this asymmetric relationship (Hatemi-J, 2012: 448). In addition to the causality relationship, the asymmetric analysis is also useful to examine dynamic relationship (such as regime-switching effects, down/upward movements of business cycles).

Besides asymmetric relations, there is one more situation in contrast to the linearity in causality analysis. Linearity assumes the stability of the variables in the long run. However, this might not be valid all the time. Variables have time-varying and time-invariant components. The time-varying components might not be stable in the long run and thus it reflects another kind of causality, namely timevarying causality/variance volatility. Moreover, the time-varying causality is related to the structural and nonlinear characteristics of the variables. This causality measures the volatility of the variables sourcing from the variance of the model. In this condition, traditional Granger causality analysis results in misleading and low explanatory power for the estimations (Maki, 2016: 777-778).

The relationship between the public and private sectors becomes more critical if timevarying properties are proven for DEC. Planning forward-looking policies depends on the outlook of the private sector. If policymakers ignore this outlook and unstable/ volatile links between them, the forecasting process might be harder. Under these circumstances, the aftermath of the implementation of a policy can be predicted efficiently by detecting time-varying causality.
In the literature, there are numerous studies for crowding-out/in effects but there are limited studies about the asymmetric causality and time-varying causality measuring public sector effects on the private sector. The contributions of this paper are the analysis of crowding-out effects of public investment at an asymmetrical causality base and the existence of a nonlinear and time-varying causal relationship between the public and private sectors.

The rest of this paper is organized as follows. The following chapter summarizes the related literature. The third chapter explains the methodology and data. The last chapter demonstrates the results of the analysis and indicates policy implications.

\section{LITERATURE REVIEW}

In the context of causality, there are many studies investigating crowding-in or/and out effects and cointegration relationships during the last decades. The literature review in this study takes this relationship into consideration and hence, has two objectives. The first objective is to gather the empirical results from available analyses in the literature in terms of crowding-in and crowding-out effects. The second purpose is to observe the preferred causality context by following the asymmetric linear, non-linear, and time-varying causality analysis in examining the crowding-in and out effects. For this purpose, the literature summary is given in Table 1.

Table 1 presents the studies examining crowding-in and crowding-out effects in the literature. These studies directly determine the validity of these effects with different results. For instance, Ramírez (1994), Erenburg and Wohar (1995), Yavuz (2001), Kuştepeli (2005), Glass (2009), Hatano (2010), Eden and Kraay (2014), and Abiad et al. (2015) detect a crowding-in effect. In other words, these papers claim that a rise in public investment/spending crowds in private investment/spending. On the other hand, the crowding-out effects are valid for some studies such as Carrasco (1998), Voss (2002), 
Mountford and Uhlig (2005), Başar and Temurlenk (2007), Afonso and Sousa (2011), Furceri and Sousa (2011), Felice (2016), Bom (2017), Kaytancı (2017), Mallick et al. (2018)

and Funashima and Ohtsuka (2019). They indicate that an increase in public investment/spending crowds out private investment or spending.

Table 1: Literature summary

\begin{tabular}{|c|c|c|c|c|}
\hline Author (s) & Period & Country & Method & Result \\
\hline Ramírez (1994) & $1950-1988$ & Mexico & Granger causality & PUB crowds in PRI \\
\hline Erenburg and Wohar (1995) & 1954-1989 & The USA & Granger causality & PUB crowds in PRI \\
\hline Carrasco (1998) & $1970-1997$ & The USA & $\begin{array}{l}\text { Regression (Cebula's } \\
\text { model) }\end{array}$ & $\begin{array}{l}\text { An increase in budget deficits will crowd out } \\
\text { private investment. }\end{array}$ \\
\hline Yavuz (2001) & 1990: Q1-2000: Q4 & Turkey & Linear Causality & $\begin{array}{l}\text { There is no causality relation between PUB } \\
\text { and PRI }\end{array}$ \\
\hline Voss (2002) & 1947: Q1- 1988: Q1 & Canada, USA & VAR & PUB tends to crowd out PRI \\
\hline Bilgili (2003) & 1988: Q1-2003: Q1 & Turkey & VECM, IRA & $\begin{array}{l}\text { PUB crowds out; whereas it's GE crowds-in the } \\
\text { PRI. }\end{array}$ \\
\hline Kuştepeli (2005) & $\begin{array}{l}1963-2003 \\
1967-2003\end{array}$ & Turkey & Johansen cointegration & GE crowds in PRI. \\
\hline Mountford and Uhlig (2005) & $1955-2000$ & The USA & VAR & GE shocks crowd out PRI. \\
\hline Chakraborty (2006) & $1970-2003$ & India & Asymmetric VAR & $\begin{array}{l}\text { There is no real crowding out between PUB } \\
\text { and PRI }\end{array}$ \\
\hline Başar and Temurlenk (2007) & $1980-2005$ & Turkey & SVAR & GE crowds out PRI. \\
\hline Saibu and Oladeji (2007) & $1960-2004$ & Nigeria & Asymmetric Causality & $\begin{array}{l}\text { Asymmetric causality is valid for MP and } \\
\text { symmetric causality is valid for FP }\end{array}$ \\
\hline Afonso and St. Aubyn (2009) & $1960-2005$ & $\begin{array}{l}14 \text { EU countries and } \\
\text { Canada, Japan, The USA }\end{array}$ & VAR & $\begin{array}{l}\text { Crowding-out/ in effects are valid for different } \\
\text { countries. }\end{array}$ \\
\hline Afonso and Sousa (2011) & 1979: Q1-2007: Q4 & Portugal & SVAR & GE crowds out PRI. \\
\hline Glass (2009) & $1959-2003$ & The USA & $\begin{array}{l}\text { VECM, Granger } \\
\text { Causality }\end{array}$ & $\begin{array}{l}\text { Granger causality is between changes in } \\
\text { output and in GE }\end{array}$ \\
\hline Hatano (2010) & $1955-2004$ & Japan & $\begin{array}{l}\text { Johansen cointegration, } \\
\text { Granger causality }\end{array}$ & PUB crowds in PRI \\
\hline Furceri and Sousa (2011) & $1960-2007$ & 145 countries & Panel data analysis & GE crowds out PRI \\
\hline Hatemi-J (2011) & 1993: Q1-2010: Q4 & $\begin{array}{l}\text { Denmark, Norway, } \\
\text { Sweden }\end{array}$ & Asymmetric Causality & Causal relationship differs from counties \\
\hline Malizard (2013) & $1960-2010$ & France & VAR, Granger Causality & Bidirectional causality between EG and MEX. \\
\hline Eden and Kraay (2014) & $1980-2012$ & $\begin{array}{l}39 \text { low-income } \\
\text { countries. }\end{array}$ & $\begin{array}{l}\text { Regression, CES } \\
\text { Production Function }\end{array}$ & There is crowding in effect. \\
\hline Şen and Kaya (2014) & $1975-2011$ & Turkey & VAR & $\begin{array}{l}\text { PUTR, GE, and PUIS crowd out PRI, whereas } \\
\text { PUCS crowds in PRI. }\end{array}$ \\
\hline Abiad et al. (2015) & $1985-2013$ & 17 OECD countries & STVAR & PUB crowds in PRI, and reduces UR \\
\hline Dreger and Reimer (2016) & $1991-2012$ & 12 Euro Area members & Panel co & Crowding in effect of PUB in long run. \\
\hline Felice (2016) & $1996-2011$ & 26 EU members & OLS & There is small crowding out effect. \\
\hline Bom (2017) & $1995-2015$ & Euro Area members & Log-linearization model & $\begin{array}{l}\text { Private capital is crowded out because of } \\
\text { decreasing in PUCF marginal productivity in } \\
\text { long run. }\end{array}$ \\
\hline Chen et al. (2017) & $\begin{array}{l}\text { 1994: Q1- } \\
\text { 2014: Q4 }\end{array}$ & China & ARDL & $\begin{array}{l}\text { EJV crowds in domestic investment, WFFE } \\
\text { crowds it out }\end{array}$ \\
\hline Hatemi-J et.al. (2017) & $1988-2013$ & $\begin{array}{l}\text { China, Japan, France, } \\
\text { Russia, Saudi Arabia, } \\
\text { and the USA }\end{array}$ & $\begin{array}{l}\text { Asymmetric Panel } \\
\text { Causality }\end{array}$ & $\begin{array}{l}\text { There is a causality relation (direction is } \\
\text { different for each countries). }\end{array}$ \\
\hline Kaytanci (2017) & 1985: Q4-2016: Q2 & Turkey & ARDL & Crowding-out effect is valid \\
\hline Mallick et al. (2018) & $1980-2014$ & India & $\begin{array}{l}\text { ARDL, Bayer and Hanck } \\
\text { cointegration }\end{array}$ & There exists crowding out effect in oil sector. \\
\hline Mensi et al. (2018) & 1992: Q1- 2014: Q4 & Saudi Arabia & $\begin{array}{l}\text { Non-parametric } \\
\text { Causality }\end{array}$ & $\begin{array}{l}\text { There is no causality relation between non-oil } \\
\text { GDP and other variables. }\end{array}$ \\
\hline Ari et al. (2019) & $1960-2015$ & GCC countries & $\begin{array}{l}\text { VAR, Linear and non- } \\
\text { linear Causality }\end{array}$ & $\begin{array}{l}\text { Non-linear causality is valid between PUB and } \\
\text { PRI }\end{array}$ \\
\hline $\begin{array}{l}\text { Funashima and Ohtsuka } \\
\text { (2019) }\end{array}$ & 2001-2013 & 47 prefectures of Japan & MCMC method & There is crowding out effects of GE \\
\hline
\end{tabular}

*Abbreviations; GDP for gross domestic product, PRI for private investment, PUB for public investment, EXR for exchange rate, INR for interest rate, GE for government expenditures, PCS for total private net capital stock, total federal, FSL for state and local total net capital stock, GC for government consumption, PC for private final consumption, EJV for equity joint venture, WFFE for wholly foreign funded enterprise, UR for unemployment rate, PUTR for government current transfer spending, PUCS for government capital spending, PUIS for government interest spending, MEX for military expenditure, FP for fiscal policy, MCMC for Markov chain Monte Carlo, MP for monetary policy, EG for economic growth, PUCF for gross fixed capital formation of general government, PRCF for private capital, PNI for private non-residential investment, IRA for impulse response analysis. 
In the literature, for instance, Voss (2002), Mountford and Uhlig (2005), Chakraborty (2006), Afonso and St. Aubyn (2009), Malizard (2013), Şen and Kaya (2014), and Ari et al. (2019) followed vector autoregression (VAR) model. Başar and Temurlenk (2007), and Afonso and Sousa (2011) launched the structural VAR (SVAR) technique. Abiad et al. (2015) conducted a smooth transition VAR (STVAR) and Chen et al. (2017) and Mallick et al. (2018) considered the autoregressive distributed lag (ARDL) method.

The remaining studies focused on the causality between the public investment and the private investment with different kinds of causality analyses such as; Granger linear or non-linear causality (Ramirez 1994; Erenburg and Wohar 1995; Glass 2009; Hatano 2010; Malizard 2013 and Ari et al. 2019), asymmetric causality (Saibu and Oladeji 2007; Hatemi-J 2011; Hatemi-J et.al. 2017) and non-parametric causality (Mensi et al. 2018). All studies found causal relationships with a different concept.

Briefly, most studies often use the cointegration analyses for the validity testing of the crowding-out/in effects in the literature. As mentioned before, the motivation of this study is that the limited number of studies uses nonlinear causality analyses, and no studies attempt to determine the time-varying causality between the investments of the government sector and private sector. So, this study distinguishes it from other studies in the literature.

\section{METHODOLOGY AND EMPIRICAL ANALYSIS}

\subsection{Methodology}

In this chapter, the Toda-Yamamato method (1995) is employed for the linear asymmetric causality and Diks-Panchenko method (2006) is used for the time-varying causality. Furthermore, Broock-Dechert-Scheinkman: BDS (1987) detects whether there is a nonlinear relationship between the variables before making a nonlinear causality analysis. 3.1.1 Asymmetric-linear causality
Before running causality testing, co-integrated relations must be checked. Engle-Granger method is used for this purpose. There is a simple logic behind this method. If two time series are not stationary at their levels, but integrated of order I(1), they might be cointegrated and hence they might not be spurious (Gujarati and Porter, 2009: 462; Koop, 2005: 168-169). As if $y$ and $x$ are dependent and explanatory variables, respectively, the model is;

$y=\alpha_{0}+\alpha_{1} x+u_{t}$

$\Delta \hat{u}_{t}=\gamma \hat{u}_{t-1}$

Engle-Granger (1987) method runs a unit-root test for the residuals produced from the estimated equation (1) and compares the tvalue of $\hat{u}_{t-1}$ with the table statistics developed by Engle-Granger (Gujarati and Porter, 2009: 169). If the absolute value of the t-test statistic is greater than the critical value, the null hypothesis is rejected and thus, the existence of a cointegration relationship of two variables is confirmed.

Stationarity is checked with Durbin-Watson table statistics. After checking, the asymmetry analysis could be run. Then, integrated variables are separated according to the shocks.

Integrated $y$ and $x$ also follow a random walk process (Hatemi-J, 2012: 449-450);

$$
\begin{aligned}
& \mathrm{y}_{1 \mathrm{t}}=\mathrm{y}_{1 \mathrm{t}-1}+\mathrm{u}_{1 \mathrm{t}}=\mathrm{y}_{10}+\sum_{\mathrm{i}=1}^{\mathrm{t}} \mathrm{u}_{1 \mathrm{i}} \\
& \mathrm{x}_{2 \mathrm{t}}=\mathrm{x}_{2 \mathrm{t}-1}+\mathrm{u}_{2 \mathrm{t}}=\mathrm{x}_{20}+\sum_{\mathrm{i}=1}^{\mathrm{t}} \mathrm{u}_{2 \mathrm{i}}
\end{aligned}
$$

If shocks are separated as positive and negative according to the variables; the following equations are obtained:

$$
\begin{aligned}
& \mathrm{y}_{1 \mathrm{t}}=\mathrm{y}_{1 \mathrm{t}-1}+\mathrm{u}_{1 \mathrm{t}}=\mathrm{y}_{1,0}+\sum_{\mathrm{i}=1}^{\mathrm{t}} \mathrm{u}_{1 \mathrm{i}}^{+}+\sum_{\mathrm{i}=1}^{\mathrm{t}} \mathrm{u}_{1 \mathrm{i}}^{-} \\
& \mathrm{y}_{2 \mathrm{t}}=\mathrm{y}_{2 \mathrm{t}-1}+\mathrm{u}_{2 \mathrm{t}}=\mathrm{y}_{2,0}+\sum_{\mathrm{i}=1}^{\mathrm{t}} \mathrm{u}_{2 \mathrm{i}}^{+}+\sum_{\mathrm{i}=1}^{\mathrm{t}} \mathrm{u}_{2 \mathrm{i}}^{-}
\end{aligned}
$$




\section{H.H. BA $\breve{G L T A S ̧, ~ P . ~ G E N C ̧ O G ̆ L U ~}$}

Asymmetrical effects are founded through different reactions for positive and negative shocks. Each shock (positive or negative) might have a permanent effect on the related variable (Hatemi-J, 2012: 448-449).

This analysis uses VAR structure taking all variables as endogenous in the same system and this is an advantage for bilateral causality testing to see causal relationships simultaneously. Furthermore, in causality analysis, the impact of one variable on another variable is seen as delayed. Therefore, the lag length is important both for causality analysis and the VAR system (Gujarati and Porter, 2009: 653).

VAR analysis checks asymmetrical causality in crowding-out effect by following the TodaYamamato (1995) method proposing a process that does not care about the order of the integration. As a result, it becomes an elastic and easy technique. This methodology uses $\operatorname{VAR}(d+p)$ system augmented with integration level and $d$ refers to the degree of integration and $p$ refers to lags of the variable (Hacker and Hatemi-J, 2006: 1490; Özcan, 2015: 184);

$y_{t}=v+A_{t} y_{t-1}+. .+A_{p} y_{t-p}+. .+A_{p+d} y_{t-p-d}+\varepsilon_{t}$

Depending on equation (6) and bootstrap distribution, modified Wald (M-wald) statistics is derived. This test statistics is asymptotically $\mathrm{X} 2$ distributed, and degree of freedom is equal to "p." Null hypothesis tests non-Granger causality and if it is rejected, there is an asymmetrical causality from $\mathrm{x}$ to $\mathrm{y}$.

Toda-Yamamato method investigates asymmetrical linear causality. If the nonlinear asymmetrical causality is searched, the first step is to detect the nonlinearity between the variables with BDS (1987) test statistics. Later, nonlinear asymmetric relations will be searched with Diks and Panchenko (2006) method.

\subsubsection{Nonlinear causality}

Broock et al. (1996) generates and enlarges the original BDS (1987) nonlinearity testing. The deterministic part of the nonlinear dynamics, such as chaos theory and model specification and standard testing procedure before nonlinear analysis, employs BDS statistics. This test determines whether nonlinearity is prevailing or not. "Portmanteau test" is a common term because of using the residuals of the estimated model. At this stage, the model specification must be made to escape an illusionary causality. However, it does not specify the shape of the nonlinear relationship (Broock et al., 1996:23; Enders, 2010: 436-437; Nazlioglu et al, 2014: 319).

While detecting nonlinearity, the null hypothesis is constructed under the assumptions of identically and independently distributed (i.i.d.) errors and finite variances (Broock et al. 1996). The null hypothesis is a test of the linearly dependent series. Rejection of the hypothesis means that nonlinearity exists between the series. The test has a simple logic based on the distance between a set of pairs of one series (different observations) or corresponding points of two series. All distance measurements and test statistics are calculated with these distances (Akintunde et al, 2015: 185).

After nonlinearity confirmation, the Diks and Panchenko (2006) method is applied to the variables for nonlinear asymmetry control. They develop a new and universal test statistic to overcome rejection redundancy because of excess sensitivity to the conditional dependence (p. 1648-1651).

The test statistics is also robust to the issues of nuisance parameters. It is an average measure of local conditional dependency (an average over local BDS test statistics). The null hypothesis implies that $X_{t}$ is not Granger cause of $Y_{t}$ and it can be stated by Generalized Autoregressive Conditional Heteroscedasticity (GARCH) process (Diks and Panchenko, 2006: 1648-1651);

$X_{t} \sim N\left(0, c+a Y_{t-1}^{2}\right)$ and $Y_{t} \sim N\left(0, c+a Y_{t-1}^{2}\right)$

At equation (7), the coefficients $c$ and $a$ are respectively $c>0$ and $0<a<1$ and these criteria guarantee that the process is stationary and ergodic. Depending on the weighted matrix, the null hypothesis implies (Diks and Panchenko, 2006: 1648-1651); 
$q_{g}=E\left[\left(\frac{f_{X, Y, Z}(X, Y, Z)}{f_{Y}(Y)}-\frac{f_{X, Y}(X, Y)}{f_{Y}(Y)} *\right.\right.$

$\left.\left.\frac{f_{Y, Z}(Y, Z)}{f_{Y}(Y)}\right) g(X, Y, Z)\right]=0$

for diminishing values of terms inside the round bracket, the test statistics prone to zero. $g(X, Y, Z)$ is a positive weight function. The value of $\mathrm{Z}$ is equal $Y_{(t+1)}$. Equation (8) represents the probability density function and the null hypothesis in terms of ratios of joint distributions.

\subsubsection{Time Varying Causality (Variance} Volatility/Spillovers)

The last analysis is variance volatility measurement. Causality analyses miss some points if time-varying causality is not taken into consideration. Hence prediction power is confirmed but the volatility is unsought (Bayat et al., 2015: 274). There are three types of timerelated causalities time domain, frequency domain, and time-varying causalities. Timedomain causality is a basic Granger causality coming from the past to the present (Cekic et al., 2017: 5). Frequency domain causality runs in a dynamic perspective and it uses different frequencies (Ciner, 2011: 499). If the frequency domain is integrated over all frequencies, the Granger causality concept produces the timedomain (Zou et al., 2010: 4) but the main differences are that the time-domain shows a certain variation and the frequency-domain measures the degree of this variation in a time series (Gokmenoglu et al, 2019: 657).

Time-varying causality focuses on the unstable part of the time. If causal relations change with time, this analysis could be made. Varying causality with time means that there are serial correlations in observations and the test statistics of this analysis relaxes fixed autocorrelation assumption while two others assume reverse Cekic et al., 2017: 15). Thus, the asymmetric causality-in variance is in question. Hafner and Herwartz (2006) apply the Lagrange Multiplier (LM) test and require stationary variables. In addition, LM specification uses the GARCH approach allowing time-dependent volatility. Furthermore, test statistics is the average value of the univariate estimation of GARCH (p,q) process and has chi-square distribution (Hafner and Herwartz, 2006: 138; Lundbergh and Teräsvirta, 2002: 420);

$\lambda_{L M}=\frac{1}{4 T}\left(\sum_{t=1}^{T}\left(\varphi_{i t}^{2}-1\right) z_{j t}^{\prime}\right) V\left(\theta_{i}\right)^{-1}\left(\sum_{t=1}^{T}\left(\varphi_{i t}^{2}-1\right) z_{j t}\right)$

$\stackrel{d}{\rightarrow} \chi^{2}$ (d.f.)

In a probability space, under the null hypothesis of LM testing $\left(H_{0}: \pi=0\right)$ and with the assumption of stationary error terms $\left(\varepsilon_{t}\right)$, $\varphi_{i t}$ is standardized residuals and $z_{j t}$ is a function of the square of error terms and variance; $z_{j t}=\left(\varepsilon_{j t-1}^{2}, \sigma_{j t-1}^{2}\right), g_{t}=1+z_{j t}^{\prime} \pi$ and $\varepsilon_{j t}=$ $\varphi_{i t} \sqrt{\sigma_{i t}^{2} g_{t}}$. Also, $\mathrm{V}\left(\theta_{\mathrm{i}}\right)$ is equal (Hafner and Herwartz, 2006: 139).

$V\left(\theta_{i}\right)=\frac{\kappa}{4 T}\left(\sum_{t=1}^{T} z_{j t} z_{j t}^{\prime}-\sum_{t=1}^{T} z_{j t} x_{i t}^{\prime}-\right.$ $\left.\left(\sum_{t=1}^{T} x_{i t} x_{i t}^{\prime}\right)^{-1} \sum_{t=1}^{T} x_{i t} z_{j t}^{\prime}\right)$

and

$\kappa=\frac{1}{T} \sum_{t=1}^{T}\left(\varphi_{i t}^{2}-1\right)^{2}$

In the context of Equations (9) and (10), the null hypothesis is constructed "non-causality in variance". If chi-square statistics is greater than the critical value, the null hypothesis is rejected.

\section{EMPIRICAL ANALYSIS}

Quarterly Turkish data from 1998Q1 to 2016Q2 from production statistics are taken from the Central Bank of Turkey (CBRT). The availability of data and the base year factor (1998Q1) determines the time series dimension. Variables are government investment (lginv) and private investment (lpinv). They are used with logarithmic values at constant price based on 1998. The 9th version of Eviews and the 10th version of Gauss is used for the analyses.

4.1 Unit-root and Cointegration Analysis

Econometric analyses start with unit root analyses and this analysis is a necessary step for a reliable regression and controlling cointegrated relationships between the variables. Then, if stationary levels of the variables are the same and residuals getting from the regression are stationary, the integration of two series is confirmed. Inpinv and lnginv are I (1) at both intercept and trend + intercept model according to the ADF test 


\section{H.H. BA $\breve{G L T A S ̧, ~ P . ~ G E N C ̧ O G ̆ L U ~}$}

statistics. Because of routine unit-root testing, test results are not listed here. Then, cointegrated relation is investigated for the variables. When we regress these two variables, we get the following model.

lpinv $=7.1776+0.5898 *$ lginv

Residuals are tested against the unit-root, the equation is;

$\Delta \hat{u}_{t}=-0.1261 * \hat{u}_{t-1}$

When t-statistic (-2.8664) is compared to the Engle-Granger critical value (\% 5; -2,986 and \% $10 ;-2.599)$; it can be seen that variables have a cointegration relationship at 10 percent significance level. Integrated series also might have a causal relationship from one to another or both two sides (Gujarati and Porter, 2009: 463-464).

4.2 Causality Analysis (Asymmetric, Nonlinear, and Time-varying)

At the beginning of the causality analysis in the VAR system, the maximum lag length is determined. After choosing maximum lag, we can choose the best lag by diminishing lag one by one with the help of the information criteria. The general tendency is approximately $T^{1 / 3}$ ( $\mathrm{T}$ is the number of observations). More lags might be considered under the suspicion of seasonality (Enders, 2010: 397). In this paper, we have quarterly data and start with 12 lags, and the 4th lag is selected by the Schwarz Information Criterion (SIC). After the determination of the lag length, the TodaYamamoto method is utilized to check asymmetries in reaction to the positive and negative shocks. Table 2 presents the results.

In agreement with $\mathrm{p}$-value and M-wald statistics, the null hypothesis asserting the noncausal relationship from lginv to lpinv is rejected in Table 2. There is a unidirectional relationship from lginv to Ipinv. After that, the effects of shocks are separated, and the results are consistent with macro-economic theory. If there is an increase in government investment, a crowding-out effect in private investment is observed or a positive shock in lginv causes to a negative shock in Ipinv. But the inverse causal relationship is not confirmed for the series. It means that a negative shock in government investment does not cause a positive shock in private investment.

Table 2: Asymmetric Toda-Yamamoto Granger Causality

\begin{tabular}{|c|c|c|c|c|c|c|}
\hline \multirow[b]{2}{*}{$\begin{array}{l}\text { Shocks De- } \\
\text { composition }\end{array}$} & \multirow[b]{2}{*}{ Lag } & \multirow[b]{2}{*}{$\begin{array}{c}\text { M- } \\
\text { wald }\end{array}$} & \multirow[b]{2}{*}{$\begin{array}{c}\text { p- } \\
\text { value }\end{array}$} & \multicolumn{2}{|c|}{$\begin{array}{l}\text { Bootstrap } \\
\text { Values }\end{array}$} & \multirow{2}{*}{$\begin{array}{r}\text { Critical } \\
10 \%\end{array}$} \\
\hline & & & & $1 \%$ & $5 \%$ & \\
\hline $\begin{array}{l}\operatorname{lpinv} \neq> \\
\operatorname{lginv}\end{array}$ & 4 & 7.081 & 0.132 & 16.506 & 10.532 & 8.543 \\
\hline $\begin{array}{l}\operatorname{lginv} \neq> \\
\operatorname{lpinv}\end{array}$ & 4 & 11.819 & 0.019 & 15.403 & 10.330 & 8.323 \\
\hline $\begin{array}{l}\operatorname{lginv}+\neq> \\
\operatorname{lpinv}+\end{array}$ & 1 & 0.585 & 0.444 & 7.078 & 4.266 & 2.795 \\
\hline $\begin{array}{l}\operatorname{lgin} v+\neq> \\
\operatorname{lpinv}-\end{array}$ & 4 & 20.940 & 0.000 & 15.608 & 11.583 & 8.897 \\
\hline $\begin{array}{l}\operatorname{lginv}-\neq> \\
\operatorname{lpinv}-\end{array}$ & 1 & 1.838 & 0.175 & 9.972 & 4.970 & 3.043 \\
\hline $\begin{array}{l}\lg \operatorname{linv}-\neq> \\
\operatorname{lpinv}+\end{array}$ & 4 & 2.059 & 0.725 & 19.700 & 12.646 & 10.125 \\
\hline
\end{tabular}

Prior to the nonlinear asymmetric causality analysis, BDS testing is run, and test results are seen in Table 3;

Table 3: BDS test statistics

\begin{tabular}{ccc}
\multicolumn{2}{c}{$\left(H_{0}:\right.$ lginv and lpinv are linearly dependent) } \\
Dimension & BDS Statistic & Prob. \\
\hline 2 & $0.104611(0.006789)$ & 0.0000 \\
3 & $0.185231(0.010883)$ & 0.0000 \\
4 & $0.240108(0.013066)$ & 0.0000 \\
5 & $0.281082(0.013730)$ & 0.0000 \\
6 & $0.300512(0.013348)$ & 0.0000 \\
\hline
\end{tabular}

* Standard deviations are in parenthesis.

Table 3 shows the nonlinearity existence between the variables. The next stage is to examine nonlinear causality and direction in Table 4.

Table 4: Nonlinear Causality results-Diks \& Panchenko (2006)

$\left(H_{0}: \operatorname{lginv}\right.$ is not Granger cause for lpinv) lpinv $\neq>$ lpinv

\begin{tabular}{ccc}
\hline \hline Lag & T_T2 & p-value \\
\hline 1 & 0.142229 & 0.556551 \\
2 & 0.192198 & 0.576206 \\
3 & 0.639658 & 0.738803 \\
4 & 0.898818 & 0.815625 \\
& lpinv $\neq$ lginv & \\
\hline 1 & 2.170113 & $\mathbf{0 . 0 1 4 9 9 9}$ \\
2 & 1.630745 & $\mathbf{0 . 0 5 1 4 7 2}$ \\
3 & 0.985658 & 0.162150 \\
4 & 0.359430 & 0.640363 \\
\hline \hline
\end{tabular}


Table 4 illustrates the statistics of two tests. It could be seen that lginv is not the nonlinear cause of lpinv. But there is a nonlinear causality from lpinv to lginv for one lag at \% 5 significance level and for two lags at \% 10 significance level. We conclude that there is unidirectional nonlinear causality from Ipinv to lginv. The last analysis is the time-varying causality measuring volatility in variances. Test results are represented in Table 5.

Table 5: Time Varying Causality $\left(H_{0}\right.$ : There is non - causality in variance)

\begin{tabular}{llr}
\multicolumn{1}{c}{ Causality-in-variance } & LM-stat & p-value \\
\hline lginv to lpinv & 2.746 & 0.2533 \\
lpinv to lginv & 8.574 & 0.0137 \\
\hline
\end{tabular}

As seen in Table 5 , there is a time-varying causality from lpinv to lginv. This is an interesting point while asymmetric linear causality points out from lginv to lpinv. So, an increase in government investment causes a decrease in private investment. This result confirms crowding-out effect of government investment purchases. But nonlinear and time varying causalities suggest controversial situation. Changes in private sector investment lead to nonlinear changes in public investments. Also, the time-varying causality testing means that volatility in government investments due to of volatility in private investments. Because, some bottlenecks like a financial crisis (local or global), demand structure changes, dead loans, and recessions cut the private sector activities at the first stage. Especially, small, and medium sizes companies are affected primarily, and this process might be resulted in bankrupts because of outstanding debts. Thus, bankrupts cause private sector to become tighter, and they have to decrease their investment purchases. Inevitably, the government has to take the role of the private sector in the economy.

\section{CONCLUSION}

Interactive relationships between the agents of private and public are sophisticated, and this relationship is attractive for the analyses from the beginning of theoretical economics. This interaction could be seen through the causal effects of policy implementations. When expansionary fiscal policy is implemented, if it stimulates the private sector, there is a crowding-in effect. On the other side if the fiscal policy makes private sectors narrower; the crowding-out effect occurs.

In this paper, firstly we use asymmetric causality of the Toda-Yamamoto method (1995) to catch up with this causality between the government investment and private investment. Asymmetric linear causality testing reveals that the crowding-out effect is valid for Turkey. It means that an increase in government investment causes a decrease in private investment. But the contrary situation is not true and a decrease in government investment does not cause any change in private investment.

Despite asymmetric linear causality results, when we look at nonlinearity detection of these variables, BDS testing shows a nonlinear relationship. Nonlinear causality and timevarying causality illustrate that causality direction is from the private investment to the government investment and volatility in government investment stems from private investment in Turkey. Moreover, the effect of private investment on government investment is nonlinear and changeable over time. Thus, the consequences of this effect could not be forecasted efficiently.

Policy recommendations: In eliminating or diminishing crowding-out effect, policy-makers can use some policies. Firstly, interest rates play a significant role in the crowding-out process. The level of interest rates might be held steady and lower by the government in Turkey. Secondly, expansionary fiscal policies could be financed with tax revenues instead of treasury bonds. Tax revenues could be risen by legal and structural regulations.

Furthermore, policy-makers must constitute a stable macroeconomic environment to solve volatility of problems in the private sector. A stable macroeconomic environment means a predictable future, and policy makers can 


\section{H.H. BAĞLITAS, P. GENÇOĞLU}

create this future through stable values for exchange rates and inflation rate, as well as low interest rates. In addition, institutional regulations are also prominent to constitute a stronger private sector.

Future study suggestions: Nonlinear and volatility results also might indicate the necessity of another kind of nonlinear and structural analyses such as threshold autoregressive models, regime-switching models, and exponential models for further analyses. Thus, the shape of the relationship between the public and private sectors can be designed more accurately.

Moreover, the effect of the public consumption expenditure on private consumption can be analyzed to develop alternative policies in terms of nonlinear causality and time-varying causality.

\section{ACKNOWLEDGMENTS}

The subject of this paper was inspired by the article of Mario Seccareccia and Marc Lavoie entitled "Sir John and Maynard Would Have Rejected the IS-LM Framework for Conducting Macroeconomic Analysis" published at the web site of Institute for New Economic Thinking in 2015. Many thanks to Prof. Dr. Saban NAZLIOGLU for sharing his codes generously, Ass. Prof. Dr. Nail TANRIOVEN for his intense efforts in the proofreading phase and Prof. Dr. Faik BİLGİLI for guiding all the time.

\section{REFERENCES}

ABIAD, A., FURCERI, D., TOPALOVA, P. (2015), "The macroeconomic effects of public investment: evidence from advanced economies", Journal of Macroeconomics, 56, 224-240.

AFONSO, A., ST. AUBYN, M. (2009), "Macroeconomic rates of return of public and private investment: crowding-in and crowding-out effects", The Manchester School, 77, 21-39.

AFONSO, A., SOUSA, R. M. (2011), "The macroeconomic effects of fiscal policy in Portugal: a Bayesian SVAR analysis", Portuguese Economic Journal, 10(1), 61-82.

AKINTUNDE, M. O., OYEKUNLE, J. O., OLALUDE, G. A. (2015), "Detection of nonlinearity in the time series using BDS test", Science Journal of Applied Mathematics and Statistics, 3(4), 184-192.

ARI, I., AKKAS, E., ASUTAY, M., KOÇ, M. (2019), "Public and private investment in the hydrocarbon-based rentier economies: A case study for the GCC countries", Resources Policy, $62,165-175$.

BALCERZAK, A.P., ROGALSKA, E. (2014), "Crowding out and crowding in within
Keynesian framework. Do we need any new empirical research concerning them?", Recent Issues in Economic Development, 7(2), 80-93.

BAŞAR, S., TEMURLENK, M. S. (2007), "Investigating crowding-out effect of government spending for Turkey: A structural var approach", Atatürk Üniversitesi İktisadi ve Ídari Bilimler Dergisi, 21(2), 95-104.

BAYAT, T., NAZLIOGLU, S., KAYHAN, S. (2015), "Exchange rate and oil price interactions in transition economies: Czech Republic, Hungary and Poland", Panoeconomicus, 62(3), 267-285.

BİLGİLI, F. (2003). "Dynamic implications of fiscal policy: Crowding-out or crowding-in?", Munich Personal RePEc Archive, https://mpra. ub.uni-muenchen.de/24111/, (06.12.2017).

BOM, P. R. (2017), "Factor-biased public capital and private capital crowding out", Journal of Macroeconomics, 52, 100-117.

BROOCK, W. A., SCHEINKMAN, J. A., DECHERT, W. D., LEBARON, B. (1996), "A test for independence based on the correlation dimension", Econometric Reviews, 15(3), 197 235. 
CARRASCO, M. (1998), "Crowding out and government spending", University Avenue Undergraduate Journal of Economics, 2(1), 1.

CEKIC, S., GRANDJEAN, D., RENAUD, O. (2017), "Time, frequency \& time-varying causality measures in neuroscience", https://arxiv.org/abs/1704.03177,

(06.11.2017).

CHAKRABORTY, L. S. (2006), "Fiscal deficit, capital formation, and crowding out: Evidence from India", National Institute of Public Finance and Policy. https://ideas.repec.org/p/npf/ wpaper/06-43.html, (12.02.2017).

CHEN, G. S., Yao, Y., \& Malizard, J. (2017). Does foreign direct investment crowd in or crowd out private domestic investment in China? The effect of entry mode. Economic Modelling, 61, 409-419.

CINER, C. (2011), "Eurocurrency interest rate linkages: A frequency domain analysis, International Review of Economics and Finance, 20, 498-505.

DIKS, C., PANCHENKO, V. (2006), "A new statistic and practical guidelines for nonparametric Granger causality testing", Journal of Economic Dynamics \& Control, 30, 1647-1669.

DREGER, C., REIMERS, H. E. (2016), “Does public investment stimulate private investment? Evidence for the euro area", Economic Modelling, 58, 154-158.

EDEN, K., KRAAY, A. (2014), “'Crowding-in” and the returns to government investment in low-income countries", The World Bank Policy Research Working Paper, 6781, 1-32.

ENDERS, W. (2010), Applied econometric time series. 3rd ed. United State of America: Wiley.

ENGLE, R. F., GRANGER, C. W. (1987), “Cointegration and error correction: representation, estimation, and testing", Econometrica: journal of the Econometric Society, 251-276.

ERENBURG, S. J., WOHAR, M. E. (1995), "Public and private investment: Are there causal linkages?", Journal of Macroeconomics, 17(1), 1-30.

FELICE, G. (2016), "Size and composition of public investment, sectoral composition and growth", European Journal of Political Economy, 44, 136-158.

FUNASHIMA, Y., OHTSUKA, Y. (2019), "Spatial crowding-out and crowding-in effects of government spending on the private sector in Japan", Regional Science and Urban Economics, 75, 35-48.

FURCERI, D., SOUSA, R. M. (2011), “The impact of government spending on the private sector: Crowding-out versus crowding-in effects", Kyklos, 64(4), 516-533.

GLASS, A. (2009), "Government expenditure on public order and safety, economic growth and private investment: Empirical evidence from the United States", International Review of Law and Economics, 29(1), 29-37.

GOKMENOGLU, K., KIRIKKALELI, D., EREN, B. M. (2019), "Time and frequency domain causality Testing: The causal linkage between FDI and economic risk for the case of Turkey", The Journal of International Trade \& Economic Development, 28(6), 649-667.

GRANGER, C.W.J. (1969), "Investigating causal relations by econometric models and crossspectral methods", Econometrica, 37(3), 424438.

GUJARATI, D.N., PORTER, D.C. (2009), Basic Econometrics, Singapore: Mc Graw Hill.

HACKER, R. S., HATEMI-J, A. (2006), “Tests for causality between integrated variables using asymptotic and bootstrap distributions: theory and application", Applied Economics, 38(13), 1489-1500.

HAFNER, C.M., HERWARTZ, H. (2006), “A Lagrange Multiplier Test for Causality in Variance", Economics Letters, 93, 137-141.

HATANO, T. (2010), "Crowding-in Effect of Public Investment on Private Investment", Public Policy Review, 6(1), 105-120. 


\section{H.H. BAĞLITAŞ, P. GENÇOĞLU}

HATEMI-J, A., TSANGYAO CHANG, T., CHEN, W., LIN, F., GUPTA, R. (2017), "Asymmetric Causality between Military Expenditures and Economic Growth in Top Six Defense Spenders", https://link.springer.com/content/pdf/10.10 07\%2Fs11135-017-0512-9.pdf,

(15.11.2017).

HATEMI-J, A. (2012), "Asymmetric Causality Tests with an Application", Empirical Economics, 43(1), 447-456.

HATEMI-J, A. (2011), "Asymmetric Panel Causality Tests with an Application to the Impact of Fiscal Policy on Economic Performance in Scandinavia", https://ideas .repec.org/p/pra/mprapa/55527.html, (15.04.2017).

KAYTANCI, U. B. (2017), “Türkiye'de Kamu Harcamalarının Dışlayıcılık ve Tamamlayıcılık Etkilerinin Araştırılması", Aksaray Üniversitesi İktisadi ve İdari Bilimler Fakültesi Dergisi, 9(3), 1-14.

KOOP, G. (2005), Analysis of Economic Data, John Wiley \& Sons, Ltd., https://pdfs.semanticscholar.org/97b4/919c 2d4df2dc21768c91d6b5bf3adc969136.pdf> (15.11.2017).

KUŞTEPELİ, Y. (2005), "Effectiveness of Fiscal Spending: Crowding-Out and/or CrowdingIn?", Yönetim ve Ekonomi, 2(1), 185-92.

LUNDBERGH, S., TERÄSVIRTA, T. (2002), "Evaluating GARCH Models", Journal of Econometrics, 110(2), 417-435.

MAKI, D. (2016), "Properties of Time-Varying Causality Tests in the Presence of Multivariate Stochastic Volatility", Open Journal of Statistics, 6(05), 777.

MALIZARD, J. (2013), "Opportunity Cost of Defense: An Evaluation in the Case of France", Defence and Peace Economics, 24(3), 247-259.

MALLICK, H., MAHALIK, M. K., SAHOO, M. (2018), "Is Crude Oil Price Detrimental to Domestic Private Investment for an Emerging Economy? The Role of Public Sector
Investment and Financial Sector Development in an Era of Globalization", Energy Economics, 69, 307-324.

MENSI, W., SHAHZAD, S. J. H., HAMMOUDEH, S., AL-YAHYAEE, K. H. (2018), "Asymmetric Impacts of Public and Private Investments on the Non-oil GDP of Saudi Arabia", International Economics, 156, 15-30.

MOUNTFORD, A., UHLIG, H. (2005), "What are the Effects of Fiscal Policy Shocks? V. Results from an Agnostic Identification Procedure", CEPR Discussion Papers, 3338.

NAZLIOGLU, S., KAYHAN, S., ADIGUZEL, U. (2014), "Electricity Consumption and Economic Growth in Turkey: Co-Integration, Linear and Nonlinear Granger Causality", Energy Sources, Part B: Economics Planning, and Policy, 9(4), 315-324.

ÖZCAN, C. (2015), "Turizm Gelirleri-Ekonomik Büyüme Ilişkisinin Simetrik ve Asimetrik Nedensellik Yaklaşımı ile Analizi: Türkiye Örneği", Erciyes Üniversitesi İktisadi ve İdari Bilimler Fakültesi Dergisi, (46), 177-199.

PURVIS, D.D. (1980), "Monetarism: a Review", Canadian Economics Association, 13(1), 96122.

RAMÍREZ, M. D. (1994), "Public and Private Investment in Mexico, 1950-90: An Empirical Analysis", Southern Economic Journal, 1-17.

SAIBU, M. O., OLADEJI, S.I. (2007), "Asymmetric Policy Shocks and Real Output Fluctuation in Nigeria (1960-2004)", International Journal of Applied Economics and Finance, 1-9.

SIX CAUSAL PATTERNS. (2017), "Causal Pattern in Science", https://www.cfa .harvard.edu/smg/Website/UCP/pdfs/SixCau salPatterns.pdf, (07.07. 2017).

ŞEN, H., KAYA, A. (2014), "Crowding-out or Crowding-in? Analyzing the Effects of Government Spending on Private Investment in Turkey", Panoeconomicus, 6, 631-654. 
İzmir İktisat Dergisi (İzmir Journal of Economics) , Yll:2021, Cilt: 36, Sayl: 2, ss. 315-327

CBRT. (2017), Electronic Data Delivery System. https://evds2.tcmb.gov.tr/index.php? /evds/serieMarket, (24.07.2017).

VOSS, G. M. (2002), "Public and Private Investment in the United States and Canada", Economic Modelling, 19(4), 641-664.

YAVUZ, N. Ç. (2001), “Türkiye'de Kamu Harcamalarının Özel Sektör Yatırım
Harcamalarını Dıșlama Etkisi Üzerine Ekonometrik Bir Analiz (1990-1\2000-IV)", Kamu-İs, 6(2), 47-64.

ZOU, C., LADROUE, C., GUO, S., FENG, J. (2010), "Identifying Interactions in the Time and Frequency Domains in Local and Global Networks-A Granger Causality Approach", BMC bioinformatics, 11(1), 337. 